\title{
Tubular control of renin synthesis and secretion
}

\author{
Jurgen Schnermann and \\ National Institute of Diabetes and Digestive and Kidney Diseases, National Institutes of Health, \\ Building 10, Rm 4D50, NIDDK, NIH, 10 Center Drive MSC 1370, Bethesda, MD 20892, USA \\ Josephine P. Briggs \\ National Center for Complementary and Alternative Medicine, National Institutes of Health, \\ Bethesda, MD, USA \\ Jurgen Schnermann: jurgens@intra.niddk.nih.gov
}

\begin{abstract}
The intratubular composition of fluid at the tubulovascular contact site of the juxtaglomerular apparatus serves as regulatory input for secretion and synthesis of renin. Experimental evidence, mostly from in vitro perfused preparations, indicates an inverse relation between luminal $\mathrm{NaCl}$ concentration and renin secretion. The cellular transduction mechanism is initiated by concentration-dependent $\mathrm{NaCl}$ uptake through the $\mathrm{Na}-\mathrm{K}-2 \mathrm{Cl}$ cotransporter (NKCC2) with activation of NKCC2 causing inhibition and deactivation of NKCC2 causing stimulation of renin release. Changes in $\mathrm{NKCC} 2$ activity are coupled to alterations in the generation of paracrine factors that interact with granular cells. Among these factors, generation of PGE2 in a COX-2dependent fashion appears to play a dominant role in the stimulatory arm of tubular control of renin release. $[\mathrm{NaCl}]$ is a determinant of local $\mathrm{PG}$ release over an appropriate concentration range, and blockade of COX-2 activity interferes with the $\mathrm{NaCl}$ dependency of renin secretion. The complex array of local paracrine controls also includes nNOS-mediated synthesis of nitric oxide, with NO playing the role of a modifier of the intracellular signaling pathway. A role of adenosine may be particularly important when $[\mathrm{NaCl}]$ is increased, and at least some of the available evidence is consistent with an important suppressive effect of adenosine at higher salt concentrations.
\end{abstract}

\section{Keywords}

Macula densa; Na-K-2Cl cotransporter; COX-2; Prostaglandins; Nitric oxide; Adenosine

\section{Introduction}

The early observation that "the ascending limb of the loop of Henle returns with invariable constancy to its capsule of origin" [39] was complemented considerably later by the anatomical description of the tubulovascular contact site as a conglomeration of specialized epithelial (macula densa), interstitial, endocrine, and smooth muscle cells for which the term juxtaglomerular apparatus (JGA) was coined [41, 159]. A functional role of the macula densa (MD) and the JGA was postulated by Goormaghtigh in his proposal that "physical and chemical variations in the content of the urinary tubule" might serve the dual purpose of regulating the circulatory and endocrine functions of the vascular elements [42]. The finding of an inverse relationship between plasma renin activity and sodium excretion in a variety of

(C) Springer-Verlag (outside the USA) 2012

Correspondence to: Jurgen Schnermann, jurgens Q intra. niddk . nih.gov. 
whole animal manipulations with minimal changes in arterial pressure and renal blood flow led to the proposal that a low $\mathrm{NaCl}$ concentration at the $\mathrm{MD}$ may act as a stimulator of renin release in volume-depleted states $[137,138,140]$. Acceptance of this proposal and understanding of the underlying mechanisms proved exceptionally difficult because selective and defined changes in MD signaling in vivo are not achievable without the likelihood of simultaneously changing other factors affecting renin release such as arterial pressure and adrenergic inputs. The goals of this article are to review the evidence that the activity of the MD cell cluster can modify the endocrine function of the renin-secreting cells and to summarize the complex and somewhat contradictory observations about the possible paracrine mediators responsible for this crosstalk.

\section{The anatomy of the tubular-vascular connection}

The macula densa The MD is a plaque of epithelial cells located at the distal end of the thick ascending limb (TAL). Surrounded on all sides by TAL epithelium, it is consistently located a short distance, 100 to $200 \mu \mathrm{m}$, from the end of the TAL and the abrupt transition to the distal convoluted tubule $[65,66]$. An unusually high nucleus-to-cytoplasm ratio causes the relatively dense appearance of this cell group, the distinguishing feature noted by early anatomists [159]. Basal infoldings are not present in MD cells, and while mitochondria are numerous, they are not in contact with the basal membrane, but rather scattered throughout the cytosol [65].

The contact region between the glomerulus and the tubule is established early in the development of the nephron (Fig. 1). Initially a comma shaped body is formed by the fusion of the condensing metanephric mesenchymal anlage and an out-pouching from the ureteric bud. By the time vascularization occurs, the nephron anlage has assumed an S-shaped appearance. The entire proximal tubule and the loop of Henle are formed as elongations from the lower portion of the S, with the contact (at the central bend of the $S$ ) between developing distal nephron and vascular pole maintained throughout. The lineage of the MD cell type is not known with certainty, and these early developmental events are compatible with an origin from either metanephric mesenchyme or ureteric bud. The MD cell has some morphological similarities with the collecting duct as both are cuboidal epithelia lacking basolateral infoldings, leading to the speculation that the two cell types may share a ureteric bud lineage $[4,32]$.

The extraglomerular mesangium Goormaghtigh suggested that the tubule is "soldered" to the vascular elements, and he described a polar cushion of cells joining tubule and vessels, now called the extraglomerular mesangium (EGM). The EGM cells fill the wedge-shaped space between the MD cells and the glomerular arterioles at the vascular hilum [8, 29]. The space lacks blood capillaries, a striking finding given the high density of vascularization of the renal interstitium in general $[7,8]$. Nerve endings abound on the vascular elements and on the thick ascending limb in the region before the MD, but most evidence suggests that neither the MD nor EGM cells are directly innervated [9]. Abundant gap junctions connect EGM cells with each other and couple the EGM with the vascular elements in the JGA [33, $106,131]$. The electron microscopic evidence is consistent with high expression of connexins 40 and 37 in the JGA $[5,83,156]$. No gap junctions or connexins have been found in MD cells indicating that any epithelial-vascular cross talk is likely to utilize diffusible paracrine factors.

Juxtaglomerular Granular Cells JG cells have been described as cuboidal, epithelial-like ("epithelioid") cells in the media of glomerular arteriolar walls. JG cells are the main producers of the active aspartic protease renin, as evidenced by the fact that active plasma renin falls to undetectable levels following bilateral nephrectomy [31]. With a rough 
endoplasmic reticulum, a well-developed Golgi apparatus, and numerous cytoplasmic granules, they have the fine structure of protein-secreting cells [65, 84]. The renincontaining granules are membrane-bound and contain amorphous electron-dense material believed to represent the mature form of the enzyme [7, 129]. Myofibrils and smooth muscle myosin have been described as sparse, but gene profiling has shown that JG cells express a wide spectrum of genes associated with the smooth muscle phenotype [16, 130]. In the mature rat kidney under control conditions, granular cells are clustered at the vascular pole over a length of about $30 \mu \mathrm{m}$ or about $20 \%$ of the afferent arteriole, but single ring-like renin-positive regions in more proximal locations are sometimes seen [20]. In the developing kidney and during stimulation of renin synthesis in the adult, proximal expression expands, and renin granules can be found in cells all along the afferent arteriole and in larger vessels as well, suggesting that smooth muscle cells retain the potential for renin synthesis $[19,40,114,124]$. The gap junctional connexins 40 and 37 have been shown to colocalize with renin, indicating structural connectivity among JG cells [47, 83, 143].

\section{Evidence for MD control of renin secretion}

Physiological variations in tubular urine at the MD Goormaghtigh's proposal that tubular fluid composition might affect vascular and secretory functions rests on the assumption that luminal solute concentrations at the MD are variable and may depend upon the physiological state of the animal. Because of the notion that the JGA acts as a relay station for feedback regulation of tubular flow dynamics, most studies have focused on flow rate as the main determinant of solute variability. As a consequence of the specific location of the MD cells, luminal fluid composition at this site reflects the characteristics of the TAL, an epithelium that avidly reabsorbs $\mathrm{NaCl}$, with cellular uptake being largely mediated by a $\mathrm{Na}-\mathrm{K}-2 \mathrm{Cl}$ cotransporter (NKCC2). Since the TAL epithelium has a very low water permeability, $\mathrm{NaCl}$ concentration at the TAL exit is predictably hypotonic, and the degree of hypotonicity depends upon tubular flow rate. The rate of flow leaving the proximal tubule thus becomes the dominant determinant of the $\mathrm{NaCl}$ signal at the $\mathrm{MD}$. In fact, using micropuncture and microperfusion methods in rodent kidneys, increments in loop of Henle flow rate above normal have been found to be consistently associated with increases in distal $\mathrm{NaCl}$ concentration [115]. Unexpectedly, higher distal tubule solute concentrations were also observed at very low rates of tubular flow $[46,94,116,118]$, a phenomenon that results from the addition of solutes along the segment between the inaccessible MD and the distal measuring site [116]. Overall, one may conclude that $\mathrm{NaCl}$ concentration at the $\mathrm{MD}$ is highly flow dependent, ranging from approximately 20 to $70 \mathrm{mM}$, with the lowest values reached at subnormal tubular flow rates.

Characterization of $M D$-dependent renin release A rigorous demonstration of a direct influence of the MD on renin release has been an experimental challenge of major proportion since it requires isolation of the effects of the MD from other stimuli that affect JG cells, precise knowledge of tubular fluid composition at the MD, and capture of all released renin in response to a defined perturbation. These requirements cannot strictly be met in vivo so that all direct evidence relies on an in vitro approach employing a modification of the isolated perfused tubule technique [17]. A short segment of the TAL including the MD-glomerulus contact region is isolated from the rabbit kidney and perfused with solutions of known $\mathrm{NaCl}$ concentration (Fig. 2a) [127, 128]. Suspending the perfused specimen in a slowly flowing superfusate and analyzing the collected superfusate for its renin content permits a quantitative determination of the rate of renin secretion (Fig. 2b). In this preparation, baroreceptor and regulated sympathetic inputs are safely excluded, the $\mathrm{NaCl}$ concentration at the MD is known and can be predictably altered, and all released renin can be captured and analyzed. In addition, the anatomical reduction by microdissection limits the possible sites of tubulovascular information transfer to MD cells and a limited 
number of surrounding TAL cells as the only cells present in the area of contact. While this preparation is suitable for studying the acute MD-dependent secretory response, it is not viable for long enough periods to assess chronic MD-dependent changes in renin release or renin gene expression. It is noteworthy that the isolated effect of the baroreceptor mechanism was studied in a similar in vitro preparation in which the afferent arteriole rather than the tubule was perfused. These studies have shown that increases in perfusion rate, but apparently not in perfusion pressure, inhibit renin release [12, 13, 113].

The isolated perfused tubule approach has shown definitively that increasing $\mathrm{NaCl}$ concentration in the tubular fluid at the MD suppresses renin secretion and reducing $\mathrm{NaCl}$ concentration stimulates it (Fig. 3) [44, 89, 90, 127, 136, 147]. MD-dependent renin secretion in this preparation is characterized by a rapid onset and offset following step changes in $\mathrm{NaCl}$ concentration and by reversibility of this change (Fig. 3) [89, 147]. Resolution of the $\mathrm{NaCl}$ concentration dependency of renin secretion showed that renin secretion was not altered when $\mathrm{NaCl}$ concentration was reduced from isotonicity to about 80 $\mathrm{mM}$ and that the full renin response was seen when $\mathrm{NaCl}$ concentrations were varied between 7 and $61 \mathrm{mM}$ of $\mathrm{Cl}$ and between 26 and $80 \mathrm{mM}$ of $\mathrm{Na}$ [56]. Renin secretion is asymmetrical in that a decrease of $\mathrm{Cl}$ below normal ( 47 to $7 \mathrm{mM}$ ) increases renin release by about $2 \mathrm{nGU} / \mathrm{min} / \mathrm{mM}$ whereas an increase of $\mathrm{Cl}$ above normal $(47$ to $87 \mathrm{mM})$ reduces release by only $0.4 \mathrm{nGU} / \mathrm{min} / \mathrm{mM}$ [56]. It is of note that the hypotonic $\mathrm{NaCl}$ concentration range affecting renin secretion is well in the physiological range and that it is identical to that in which the tubuloglomerular feedback (TGF) response occurs.

These studies lend credence to earlier micropuncture experiments that were interpreted as showing stimulation of renin release by a reduction of $\mathrm{MD} \mathrm{NaCl}$ concentration $[85,95]$. Indirect evidence consistent with MD control of renin release has also been obtained in the intact animal and in dogs in which kidneys had been made non-filtering by ureteral occlusion $[98,125,140]$.

\section{The sensing mechanism for MD-mediated renin secretion}

In the isolated JGA preparation, stimulation of renin secretion was found to be primarily dependent on reductions of $\mathrm{NaCl}$ concentration whereas the stimulatory effect of reductions in luminal $\mathrm{NaCl}$ load, i.e., a decrease of perfusate flow at constant $\mathrm{NaCl}$ concentration, was only marginal [89]. $\mathrm{NaCl}$ dependency of renin secretion fits well with the early conclusion from studies in intact animals that $\mathrm{MD} \mathrm{NaCl}$ transport may play a critical role in $\mathrm{MD}$ control of renin secretion $[98,137,139]$. Direct evidence for a MD-mediated effect of $\mathrm{NaCl}$ transport inhibition on renin secretion was obtained in non-perfused afferent arterioles in which furosemide stimulated renin release only when the MD segment was included in the dissected specimen, but not in its absence [60]. In the isolated perfused JGA preparation, luminal application of bumetanide $\left(10^{-6} \mathrm{M}\right)$ or furosemide $\left(5 \times 10^{-5} \mathrm{M}\right)$ increased renin secretion during perfusion with high $\mathrm{NaCl}$ solutions $[56,90]$. Furosemide has been used frequently as experimental tool to probe for participation of the MD pathway in changes of renin release in the intact animal [139]. However, interpretation of such studies may be complicated both by potential effects on extracellular fluid volume [139] and by the consequences of simultaneous inhibition of the ubiquitous NKCC1 isoform [48]. NKCC1 is expressed in blood vessels and JG cells, and recent studies in NKCC1-deficient mice have shown that plasma renin concentration is significantly elevated compared to wild-type mice $[2,21,69,93]$. Furthermore, studies in isolated JG cells indicate that furosemide can directly stimulate renin exocytosis by inhibition of NKCC1 [21]. With systemic furosemide causing inhibition of both tubular NKCC2 and extratubular NKCC1, the stimulation of renin release by loop diuretics may reflect the combined inhibition of both NKCC isoforms. In fact, luminal application of furosemide in the experiments in the isolated perfused JGA 
preparation caused only a relatively small stimulation of renin release, perhaps reflecting the fact that inhibition is limited to NKCC2 in this preparation $[56,90]$.

Although NKCC2 mediates the bulk of MD Na reabsorption, apical expression of the $\mathrm{Na}^{+} /$ $\mathrm{H}^{+}$exchanger 2 (NHE2) may contribute to $\mathrm{Na}^{+}$transport as well as to the regulation of renin release [49]. In NHE2-deficient mice renal renin content and plasma renin concentration were elevated compared to wild-type controls, and the stimulation of the renin system by a salt-depleted diet was blunted. Increased baseline renin secretion in NHE2 ${ }^{-/-}$mice was paralleled by enhanced MD COX-2 and mPGES expression.

Studies of the ion selectivity of renin release in the isolated perfused JGA have shown that the inhibitory response was unchanged when most of luminal $\mathrm{Na}$ was replaced by choline or rubidium whereas substituting $\mathrm{Cl}$ by isethionate or acetate virtually eliminated the response to increased $\mathrm{Na}$ concentrations [87]. These findings support the hypothesis that the initiating signal for $\mathrm{MD}$ control of renin secretion is a change in $\mathrm{NaCl}$ transport rate via a luminal $\mathrm{Na}-$ $\mathrm{K}-2 \mathrm{Cl}$ cotransporter whose physiological activity is determined by luminal $\mathrm{Cl}$ concentration. A role of $\mathrm{Cl}$ had been suggested in earlier studies in intact animals in which $\mathrm{Cl}$ or $\mathrm{Br}$ salts without $\mathrm{Na}$ inhibited renin secretion, whereas $\mathrm{Na}$ salts without $\mathrm{Cl}$ or $\mathrm{Br}$ as the accompanying anion did not $[75,77]$. Changes in renin secretion under these conditions correlated with loop of Henle $\mathrm{Cl}$ reabsorption [148]. An acute selective depletion of $\mathrm{Cl}$ by peritoneal dialysis increased plasma renin activity [1], and substitution of $\mathrm{Cl}$ by nitrate or thiocyanate in the perfusate of isolated kidneys stimulated renin secretion [111].

The functional links between solute transport and formation of the paracrine mediators discussed in the subsequent sections are still obscure. Activation or inhibition of specific signaling pathways in MD cells may be related to any of the distinct cellular changes associated with acute elevations of luminal $\mathrm{NaCl}$ including alterations of intracellular $\mathrm{Na}$, $\mathrm{Cl}$, and $\mathrm{Ca}$ concentrations, cytosolic $\mathrm{pH}$, or cell volume [11, 34, 86, 101-103, 105, 112]. Alternatively, changes of the extracellular milieu may activate kinases such as MAPK that are known to be exquisitely responsive to activation by extracellular signals. Different rates of $\mathrm{NaCl}$ transport are also expected to cause alterations in metabolic intermediates that may affect signaling pathways.

\section{The stimulus-response coupling mechanism}

Prostaglandins The biologically active spectrum of prostaglandins is derived from the oxygenation and peroxidation of arachidonic acid by cyclooxygenase enzymes (COX-1 and $\mathrm{COX}-2$ ) and the subsequent processing of the resulting endoperoxides (or $\mathrm{PGH}_{2}$ ) by several enzymes including PGE2 synthases. Various metabolites of arachidonic acid have been suggested to regulate renin secretion [70], but the most consistent finding is stimulation of renin secretion by prostaglandins of the $\mathrm{E}$ and I series [64, 122]. A specific role of prostaglandins in MD-dependent renin secretion gained plausibility by the discovery that the inducible cyclooxygenase COX-2 is constitutively expressed in MD and surrounding TAL cells $[27,54,91,132,142]$. A membrane-associated PGE2 synthase has also been observed in MD cells of both rats and rabbits [18, 37].

Studies in the isolated rabbit JGA have shown that acute, non-specific COX inhibition with flufenamic acid or flurbiprofen virtually abolished the increase in renin secretion caused by a decrease in $\mathrm{MD} \mathrm{NaCl}$ concentration (Fig. 4a) [44]. Since the concentration change from minimal to maximal was done in a single step, it is not clear whether the effect of these agents was symmetrical around the midpoint or whether it mainly affected the stimulation in the subnormal concentration range. Direct evidence for a role of COX-2 has been obtained in an extension of these studies in which the specific COX-2 inhibitor NS-398 was also found to prevent the stimulation of renin secretion by low $\mathrm{NaCl}$ while the putative $\mathrm{COX}-1$ 
blocker valerylsalicylate did not (Fig. 4b) [136]. The role of PGE2 in MD-dependent renin release has also been examined using in vivo methods. Support for a role of PG's in MDmediated renin release comes from studies examining the response to supraaortic constriction in denervated kidneys of dogs treated with papaverine; in this model, designed to isolate MD-dependent responses, stimulation of renin secretion was blocked by indomethacin and meclofenamate [99]. The stimulation of renin release or renin expression produced by furosemide or a low Na diet was blunted by the administration of indomethacin or the COX-2 specific inhibitor rofecoxib [6, 35, 67, 119]. Rofecoxib also normalized the elevated levels of urinary prostaglandin excretion and plasma renin activity in patients with genetically verified Bartter's syndrome due to mutations of NKCC2 or ROMK [108].

An important piece of evidence linking $\mathrm{MD} \mathrm{NaCl}$ delivery to local $\mathrm{PGE}_{2}$ release has recently been provided by the application of an in vitro technique in which cytosolic $\mathrm{Ca}$ in HEK293 cells stably transfected with the mouse $\mathrm{PGE}_{2}$ receptor EP1 was used as indicator of changes in PGE2 levels [104]. Transfected HEK cells indeed responded to $\mathrm{PGE}_{2}$ with a dose-dependent increase in $[\mathrm{Ca}]_{i}$, and this effect was blocked by the EP1 inhibitor SC51322. In dissected and perfused TAL/MD preparations from the rabbit, a transfected and fura-2 loaded sensor cell was then positioned at the basolateral aspect of MD cells, and changes in $[\mathrm{Ca}]_{i}$ were used as an index of EP1 activation. Removal of luminal $\mathrm{NaCl}$ or the presence of furosemide caused a significant increase in sensor cell $[\mathrm{Ca}]_{i}$ when the TAL/MD preparation was from a low $\mathrm{NaCl}$ fed animal. Of major importance is the observation that most of the change in $[\mathrm{Ca}]_{i}$ occurred in a $\mathrm{NaCl}$ concentration range between 20 and $40 \mathrm{mM}$, exactly the concentration range in which $\mathrm{NaCl}$ concentration affects renin secretion in a similar preparation.

The mechanisms by which a reduction in luminal $\mathrm{NaCl}$ causes stimulation of $\mathrm{PGE}_{2}$ release and COX-2 expression have been studied in cell lines derived from the MD and from TAL cells $[26,154]$. In both lines of cells, a reduction in medium $\mathrm{NaCl}$ caused a prompt and dose-dependent increase in $\mathrm{PGE}_{2}$ release that was essentially completely inhibited by NS-398 and was therefore largely mediated by COX-2. The onset of this response preceded any increase in COX-2 expression, suggesting that it was the result of an increase in COX-2 activity and/or of an activation of PLA2 followed by increased availability of arachidonic acid. Presence of PLA2 in MD cells and regulation of PLA2 in parallel to that of COX-2 has been demonstrated earlier [91]. In both TAL and MD cells in culture, a reduction in medium $\mathrm{NaCl}$ also augmented the expression of the mRNA and protein expression of COX-2 [26, 154]. Ion substitution studies indicate that the extracellular signal for COX-2 stimulation appears to be a reduction in $\mathrm{Cl}$ rather than in Na concentration, a finding that is remarkably concordant with the $\mathrm{Cl}$ dependency of renin secretion shown earlier in quite different preparations. The intracellular signaling events leading to the stimulation of COX-2 activity and expression are initiated by rapid phosphorylation of p38 and Erk1/2 kinases [154]. Participation of MAP kinases in COX-2 expression is supported by the inhibitory effects of SB 203580 and PD 98059, inhibitors of p38- and Erk1/2-mediated signaling events [26, 154]. The increased expression of COX-2 through the MAP kinase pathway appears to reflect both a transcriptional activation and an increased stability of the mRNA [25]. These observations are in agreement with findings in other cell types in which MAP kinases are critically involved in regulating COX-2 expression in response to cytokines, growth factors, and hypertonicity $[45,151,153]$.

The marked effect of COX2 in MD-controlled renin secretion has called attention to the possibility that changes of renin secretion in response to diverse interventions could be mediated by modulation of COX-2 activity. Most notable in this regard is the strong and consistent stimulation of both renin and COX-2 expression by ACE inhibition or AT1 receptor blockade and the increased COX-2 levels in AT1 receptor knockout mice [23, 27, 
150]. These observations indicate that the well-known feedback inhibition of renin release by angiotensin II may not be the reflection of a direct effect on JG cells but may be mediated by a reduction of MD COX-2.

Whereas the direct effect of activation of the Gs-linked D1-like receptors for dopamine is stimulation of renin release, the D1 agonist fenoldopam caused the opposite, a significant inhibition of renin release [157]. This indirect action of D1 activation may result from inhibition of proximal tubular fluid reabsorption and subsequent suppression of renal cortical COX-2 expression by an elevated $\mathrm{NaCl}$ at the MD. D1 agonists have in fact been shown to suppress COX-2, and the renin inhibition exerted by fenoldopam was converted to stimulation in COX-2-deficient mice [157, 158].

GPR91, until recently a $\mathrm{G}$ protein-coupled orphan receptor, has been identified as a receptor for succinate. It has been found to be localized in the apical membrane of cells of the cortical TAL including the MD and in endothelial cells of the afferent arteriole [110]. Activation of GPR91 by succinate stimulates COX-2 activity, PGE2 release, and presumably renin expression, an effect that is particularly pronounced in diabetic wild-type mice and markedly reduced in GPR91-deficient animals [141].

The role of the MD in the chronic regulation of renin synthesis and JG cell recruitment is uncertain, in part because this issue cannot be studied under the controlled conditions of the in vitro preparation. However, the abundance of COX-2 in MD and adjacent TAL cells is highly variable, and these regulatory changes are generally strikingly parallel to the regulation of renin in JG cells, providing inferential evidence for long-term effects of the MD on JG cell renin. For example, COX-2-deficient mice have markedly reduced levels of basal renin mRNA expression, plasma renin activity, and juxtaglomerular renin enzyme activity $[28,73,152]$, and COX-2 specific blockers can exert inhibitory effects on renin expression [52, 53]. Conversely, increases in COX-2 expression have been observed in rats treated chronically with furosemide and in patients with Bartter syndrome, suggesting that COX-2 expression may be in some way linked to NaCl uptake through NKCC2 [23, 67, 76, 92]. An increase of MD COX-2 expression is also induced by administration of a low $\mathrm{NaCl}$ diet or by renal artery stenosis $[54,55,63,145,155]$. Finally, stimulation of COX-2 expression has been found following partial renal ablation and in active lupus nephritis [135, 146]. In addition to inducing $\mathrm{COX}-2$ expression, a low $\mathrm{NaCl}$ diet caused a two- to three-fold increase in the expression of $\mathrm{PGE}_{2}$ synthase in $\mathrm{MD}$ cells [18]. Although it is uncertain whether the upregulation of COX-2 in these complex conditions is the direct result of altered tubular $\mathrm{NaCl}$ concentrations, a reduced $\mathrm{NaCl}$ transport by $\mathrm{MD}$ cells following a fall in GFR or an increase in proximal $\mathrm{NaCl}$ absorption may be a common feature of these diverse states. Without doubt, however, in many of these conditions, alterations in baroreceptor and sympathetic signals could also have contributed to stimulation of renin expression [58, 59, $68]$.

Nitric oxide Nitric oxide is generated from L-arginine in a complex reaction catalyzed by nitric oxide synthases and requiring the co-substrates NADPH and oxygen and the cofactors tetrahydro-biopterin, FAD, and heme. The family of NO synthases consists of at least three members, the constitutive neuronal and endothelial isoforms (nNOS and eNOS) and the inducible isoform (iNOS). The conspicuous presence of nNOS in MD cells has been of particular interest because of the proximity to renin-producing granular cells [96, 149], but endothelial cells, the classical site of eNOS expression, are also potential sources of NO with access to JG cells.

Our understanding of the role of NO in the response of renin release to an acute reduction of $\mathrm{NaCl} / \mathrm{NaCl}$ transport at the MD is incomplete. Some studies have examined the MD 
mechanism by the indirect approach of testing whether loop diuretic-induced stimulation of renin secretion is sensitive to NOS inhibitors. In dissected rat renal microvessels, NOS inhibition abolished the increase in renin release caused by furosemide pretreatment [24]. Similarly, the stimulation of renin secretion by furosemide in vivo was inhibited by the administration of NOS inhibitors [10, 107, 119]. In isolated perfused kidneys of rats and mice in which the perfusion pressure is servo-controlled, addition of L-NAME to the perfusate greatly reduced the stimulatory effect of loop diuretics on renin secretion [22, 82]. In the isolated perfused JGA preparation, another preparation in which baroreceptormediated effects can be excluded, the exclusively luminal addition of a non-specific NOS inhibitor prevented the increase in renin secretion caused by a reduction in luminal $\mathrm{NaCl}$ concentration (Fig. 5a) [57]. Taken together these observations suggest that the pathway leading from transport inhibition to stimulation of renin secretion does not operate efficiently in the absence of $\mathrm{NO}$. The requirement for $\mathrm{NO}$ in supporting low $\mathrm{NaCl}$-mediated renin secretion may not lie in a specific mediator role of MD-derived $\mathrm{NO}$, but may derive from facilitation of the operation of mediators such as PGE2 [22]. This permissive background effect of NO in the enhancement of renin secretion by an acute reduction of luminal $\mathrm{NaCl}$ may be mechanistically linked to stabilization of cAMP by inhibition of phosphodiesterase 3 thereby potentiating the effect of cAMP-dependent mediators such as PGE2 [36, 82].

While the effect of lowering $\mathrm{MD} \mathrm{NaCl}$ below normal on $\mathrm{NO}$ generation is not known, two independent studies in a comparable in vitro preparation have shown that increasing luminal $\mathrm{NaCl}$ above normal causes increased $\mathrm{NO}$ levels in MD cells as well as in their surroundings and that this increase was prevented by an inhibitor of nNOS [78, 86]. Functional support for stimulation of $\mathrm{NO}$ production by supranormal luminal $\mathrm{NaCl}$ also comes from studies showing that NOS inhibition enhances tubuloglomerular feedback-mediated vasoconstriction predominantly when $\mathrm{NaCl}$ concentration at the $\mathrm{MD}$ is high $[15,109,133$, 149]. The stimulation of MD nNOS activity by high luminal $\mathrm{NaCl}$ is probably not $\mathrm{Ca}$ dependent since $\mathrm{NaCl}$ does not consistently elevate $[\mathrm{Ca}]_{i}$ and since an activation of NOS was seen in Cafree medium [86]. The increased formation of $\mathrm{NO}$ with increases in luminal $\mathrm{NaCl}$ may be caused by cell alkalinization since the $\mathrm{pH}$ optimum of NOS is in the slightly alkaline range [34, 144]. Finally, a reduced production of PGE2 with high luminal $\mathrm{NaCl}$ may contribute to NOS disinhibition since a dose-dependent reduction of NOS expression has been observed in cultured MD cells exposed to PGE2 [100]. Whether the enhanced NO production at elevated luminal $\mathrm{NaCl}$ concentrations contributes to MD-mediated inhibition of renin release remains an interesting possibility. Renin secretion in the perfused JGA preparation tended to increase with NOS inhibition at high luminal concentrations, and the addition of Na nitroprusside to the bath inhibited renin secretion [57]. In addition, an acute and dose-dependent inhibitory effect of the NO donor Na nitroprusside on renin release has been observed in primary cultures of JG cells $[43,120]$. Inhibition of renin release by NO appears to be a direct result of the activation of cyclic guanylate kinase, and one could speculate that this inhibitory action may be dominant at supranormal NO levels [38].

As with COX-2, uncertainties surround the question whether MD signaling through the NO pathway regulates renin expression under chronic conditions. The notion that NO may play a role as a signal modifier between MD and renin-secreting cells is consistent with parallel expression of renin and MD nNOS in conditions such as low $\mathrm{NaCl}$ intake, the administration of furosemide, and renal artery constriction [14, 97, 121, 126, 134]. Thus, nNOS upregulation and a subsequent increase of $\mathrm{NO}$ generation may be an upstream signal in the stimulation of the renin axis by chronic low $\mathrm{NaCl}$ at the MD. In fact, mice with permanent deletions of nNOS have a reduced plasma renin activity, and basal renin secretion in isolated perfused kidneys from nNOS-or eNOS-deficient mice is consistently lower than in wild-type animals, suggesting that release of NO tonically upregulates renin synthesis and secretion in 
mice $[22,100]$. nNOS expression in MD cells appears to be stabilized by a negative feedback effect of angiotensin II since nNOS protein levels are markedly upregulated in AT1a- or angiotensinogen-deficient mice [71, 72]. Furthermore, angiotensin II antagonists can increase MD nNOS expression [134].

Adenosine The presence of adenosine in effective concentrations in the juxtaglomerular region of the nephron may be deduced from its role as a paracrine mediator of the tubuloglomerular feedback response [117]. In a concentration range between $10^{-10}$ and $10^{-6}$ $\mathrm{M}$, adenosine causes dose-dependent inhibition of renin secretion in isolated JG cells and kidney slices $[30,81]$. In the isolated perfused JGA preparation, bath addition of adenosine at concentrations of $10^{-6}$ and $10^{-4} \mathrm{M}$ significantly reduced the elevated levels of renin secretion caused by low luminal $\mathrm{NaCl}$ [88]. Studies with selective agonists have established that this inhibitory effect is mediated by A1AR $[3,30]$. The cellular mechanism of adenosine-dependent changes in renin secretion is not clear, but a reduction in cAMP and an increase in cGMP are potential pathways initiated by A1AR activation and leading to renin release inhibition [81]. Furthermore, A1AR agonists have been shown to cause constriction of afferent arterioles by Gi-dependent activation of phospholipase $\mathrm{C}$, cell depolarization by opening of $\mathrm{Ca}$-activated $\mathrm{Cl}$ channels, and subsequent sustained $\mathrm{Ca}$ influx through voltagedependent $\mathrm{Ca}$ channels $[50,51]$. A similar sequence of events may occur in JG cells since the $\mathrm{Ca}$ channel blocker verapamil prevented the renin inhibitory effect of high luminal $\mathrm{NaCl}$ concentrations (Fig. 5b) [56].

Endogenous adenosine appears to exert a tonic inhibitory effect on renin secretion since administration of inhibitors of A1AR such as DPCPX cause its stimulation [62, 79, 80]. This pharmacological profile of adenosine is consistent with the notion that the inhibition of renin secretion caused by an elevated $\mathrm{MD} \mathrm{NaCl}$ concentration may be at least in part adenosinemediated. Renin secretion by non-perfused afferent arterioles was found to be lower when the MD was present, and this difference could be abolished by adding adenosine to isolated afferent arterioles or theophylline to afferent arterioles dissected with the attached MD [61]. In the isolated perfused JGA, the selective adenosine ${ }_{1}$-receptor blocker 8-cyclopentyl-1,3dipropylxanthine blunted the fall in renin secretion caused by an elevation in luminal $\mathrm{NaCl}$ by about $50 \%$, but did not abolish it [147]. In contrast, however, the renin secretory response to bumetanide was not measurably altered in perfused kidneys isolated from A1AR-deficient compared to wild-type mice [123]. These two observations are not necessarily in conflict since bumetanide administration only examines the effect of a reduction in $\mathrm{NaCl}$ transport that is only about half of the $\mathrm{NaCl}$ concentration range over which the MD mechanism operates. Thus, it is conceivable that adenosine may contribute to the inhibition of renin secretion at high $\mathrm{NaCl}$ concentration but that disinhibition at low luminal $\mathrm{NaCl}$ with reduced adenosine levels is not an important drive for renin secretion. In fact, A1AR-deficient mice do not show the inhibition of renin release caused by intravenous bolus administration of saline that leads to an acute elevation of luminal $\mathrm{NaCl}$ [74]. Interestingly, repeat measurements of plasma renin concentration over a 2-week period have shown a significantly greater variability in individual A1AR-deficient compared to WT mice (Fig. 6). The greater renin instability could reflect the fact that the TGF mechanism is absent in $\mathrm{A} 1 \mathrm{AR}^{-/-}$mice, and GFR is therefore predicted to be less stabile and to result in greater variability of $\mathrm{NaCl}$ concentration at the MD. Thus, the purported role of TGF to stabilize $\mathrm{NaCl}$ excretion may be achieved not only by controlling GFR but also by minimizing variations in renin secretion.

\section{Summary}

As presciently predicted by Goormaghtigh, the composition of the tubular fluid passing the MD cells is an important determinant of renin secretion and renin synthesis. The cellular 
transduction mechanism is initiated by $\mathrm{NaCl}$ uptake through the $\mathrm{Na}-\mathrm{K}-2 \mathrm{Cl}$ cotransporter with activation of NKCC2 causing inhibition and deactivation of NKCC2 causing stimulation of renin release. Changes in NKCC2 activity are coupled to alterations in the generation of paracrine factors that interact with granular cells. This complex array of local paracrine controls includes COX-2-dependent formation of prostaglandins, nNOS-mediated synthesis of nitric oxide, and intracellular or extracellular formation of adenosine. Of these three factors, the best established regulatory role is for prostaglandins. $[\mathrm{NaCl}]$ at the $\mathrm{MD}$ is a determinant of local PG release over an appropriate concentration range, and blockade of COX-2 activity abolishes $\mathrm{NaCl}$ dependency of renin secretion in the isolated JGA preparation. The role of adenosine may be particularly important when $[\mathrm{NaCl}]$ is increased, and at least some of the available evidence is consistent with an important suppressive effect of adenosine at higher salt concentrations. The role of juxtaglomerular NO production is unclear, but some contribution of $\mathrm{NO}$ as a regulatory or permissive factor seems likely, although complete understanding is complicated due to important inputs from other cell types and the potential of both stimulatory and inhibitory actions.

\section{Acknowledgments}

Research from the laboratory of the authors was supported by intramural funds of the National Institute of Diabetes and Digestive and Kidney Diseases, National Institutes of Health, Bethesda, MD.

\section{References}

1. Abboud HE, Luke RG, Galla JH, Kotchen TA. Stimulation of renin by acute selective chloride depletion in the rat. Circ Res. 1979; 44:815-821. [PubMed: 428074]

2. Akar F, Jiang G, Paul RJ, O'Neill WC. Contractile regulation of the $\mathrm{Na}(+)-\mathrm{K}(+)-2 \mathrm{Cl}(-)$ cotransporter in vascular smooth muscle. Am J Physiol Cell Physiol. 2001; 281:C579-C584. [PubMed: 11443057]

3. Albinus M, Finkbeiner E, Sosath B, Osswald H. Isolated superfused juxtaglomerular cells from rat kidney: a model for study of renin secretion. Am J Physiol. 1998; 275:F991-F997. [PubMed: 9843917]

4. Arend LJ, Smart A, Briggs JP. Metanephric rat-mouse chimeras to study cell lineage of the nephron. Dev Genet. 1999; 24:230-240. [PubMed: 10322631]

5. Arensbak B, Mikkelsen HB, Gustafsson F, Christensen T, Holstein-Rathlou NH. Expression of connexin 37, 40, and 43 mRNA and protein in renal preglomerular arterioles. Histochem Cell Biol. 2001; 115:479-487. [PubMed: 11455448]

6. Bailie MD, Crosslan K, Hook JB. Natriuretic effect of furosemide after inhibition of prostaglandin synthetase. J Pharmacol Exp Ther. 1976; 199:469-476. [PubMed: 824442]

7. Barajas L. The development and ultrastructure of the juxtaglomerular cell granule. J Ultrastruct Res. 1966; 15:400-413. [PubMed: 4957359]

8. Barajas L. The ultrastructure of the juxtaglomerular apparatus as disclosed by three-dimensional reconstructions from serial sections. The anatomical relationship between the tubular and vascular components. J Ultrastruct Res. 1970; 33:116-147. [PubMed: 4922486]

9. Barajas L, Powers KV. Innervation of the thick ascending limb of Henle. Am J Physiol Renal Physiol. 1988; 255:F340-F348.

10. Beierwaltes WH. Selective neuronal nitric oxide synthase inhibition blocks furosemide-stimulated renin secretion in vivo. Am J Physiol Renal Physiol. 1995; 269:F134-F139.

11. Bell PD, Peti-Peterdi J. Angiotensin II stimulates macula densa basolateral sodium/hydrogen exchange via type 1 angiotensin II receptors. J Am Soc Nephrol. 1999; 10(Suppl 11):S225-S229. [PubMed: 9892168]

12. Bock HA, Hermle M, Brunner FP, Thiel G. Pressure dependent modulation of renin release in isolated perfused glomeruli. Kidney Int. 1992; 41:275-280. [PubMed: 1552701]

13. Bock HA, Hermle M, Fiallo A, Osgood RW, Fried TA. Measurement of renin secretion in single perfused rabbit glomeruli. Am J Physiol Renal Physiol. 1990; 258:F1460-F1465. 
14. Bosse HM, Bohm R, Resch S, Bachmann S. Parallel regulation of constitutive NO synthase and renin at JGA of rat kidney under various stimuli. Am J Physiol Renal Physiol. 1995; 269:F793F805.

15. Braam B, Koomans HA. Reabsorption of nitro-L-arginine infused into the late proximal tubule participates in modulation of TGF responsiveness. Kidney Int. 1995; 47:1252-1257. [PubMed: 7637254]

16. Brunskill EW, Sequeira-Lopez ML, Pentz ES, Lin E, Yu J, Aronow BJ, Potter SS, Gomez RA. Genes that confer the identity of the renin cell. J Am Soc Nephrol. 2011; 22:2213-2225. [PubMed: 22034642]

17. Burg M, Grantham J, Abramow M, Orloff J. Preparation and study of fragments of single rabbit nephrons. Am J Physiol. 1966; 210:1293-1298. [PubMed: 5923067]

18. Campean V, Theilig F, Paliege A, Breyer M, Bachmann S. Key enzymes for renal prostaglandin synthesis: site-specific expression in rodent kidney (rat, mouse). Am J Physiol Renal Physiol. 2003; 285:F19-F32. [PubMed: 12657565]

19. Cantin M, Araujo-Nascimento MD, Benchimol S, Desormeaux Y. Metaplasia of smooth muscle cells into juxtaglomerular cells in the juxtaglomerular apparatus, arteries, and arterioles of the ischemic (endocrine) kidney. An ultrastructural-cytochemical and autoradiographic study. Am J Pathol. 1977; 87:581-602. [PubMed: 869015]

20. Casellas D, Dupont M, Kaskel FJ, Inagami T, Moore LC. Direct visualization of renin-cell distribution in preglomerular vascular trees dissected from rat kidney. Am J Physiol Renal Physiol. 1993; 265:F151-F156.

21. Castrop H, Lorenz JN, Hansen PB, Friis U, Mizel D, Oppermann M, Jensen BL, Briggs J, Skott O, Schnermann J. Contribution of the basolateral isoform of the $\mathrm{Na}-\mathrm{K}-2 \mathrm{Cl}$ cotransporter (NKCC1/ BSC2) to renin secretion. Am J Physiol Renal Physiol. 2005; 289:F1185-F1192. [PubMed: 16106034]

22. Castrop H, Schweda F, Mizel D, Huang Y, Briggs J, Kurtz A, Schnermann J. Permissive role of nitric oxide in macula densa control of renin secretion. Am J Physiol Renal Physiol. 2004; 286:F848-F857. [PubMed: 15075180]

23. Castrop H, Schweda F, Schumacher K, Wolf K, Kurtz A. Role of renocortical cyclooxygenase-2 for renal vascular resistance and macula densa control of renin secretion. J Am Soc Nephrol. 2001; 12:867-874. [PubMed: 11316844]

24. Chatziantoniou C, Pauti MD, Pinet F, Promeneur D, Dussaule JC, Ardaillou R. Regulation of renin release is impaired after nitric oxide inhibition. Kidney Int. 1996; 49:626-633. [PubMed: 8648902]

25. Cheng HF, Harris RC. Cyclooxygenase-2 expression in cultured cortical thick ascending limb of Henle increases in response to decreased extracellular ionic content by both transcriptional and post-transcriptional mechanisms. Role of p38-mediated pathways. J Biol Chem. 2002; 277:4563845643. [PubMed: 12237297]

26. Cheng HF, Wang JL, Zhang MZ, McKanna JA, Harris RC. Role of p38 in the regulation of renal cortical cyclooxygenase-2 expression by extracellular chloride. J Clin Invest. 2000; 106:681-688. [PubMed: 10974021]

27. Cheng HF, Wang JL, Zhang MZ, Miyazaki Y, Ichikawa I, McKanna JA, Harris RC. Angiotensin II attenuates renal cortical cyclooxygenase-2 expression. J Clin Invest. 1999; 103:953-961. [PubMed: 10194467]

28. Cheng HF, Wang JL, Zhang MZ, Wang SW, McKanna JA, Harris RC. Genetic deletion of COX-2 prevents increased renin expression in response to ACE inhibition. Am J Physiol Renal Physiol. 2001; 280:F449-F456. [PubMed: 11181406]

29. Christensen JA, Meyer DS, Bohle A. The structure of the human juxtaglomerular apparatus. A morphometric, light microscopic study on serial sections. Virchows Arch A Pathol Anat Histol. 1975; 367:83-92. [PubMed: 808896]

30. Churchill PC, Churchill MC. A1 and A2 adenosine receptor activation inhibits and stimulates renin secretion of rat renal cortical slices. J Pharmacol Exp Ther. 1985; 232:589-594. [PubMed: 2983063] 
31. Doi Y, Franco-Saenz R, Mulrow PJ. Evidence for an extrarenal source of inactive renin in rats. Hypertension. 1984; 6:627-632. [PubMed: 6389336]

32. Fischer E, Schnermann J, Briggs JP, Kriz W, Ronco PM, Bachmann S. Ontogeny of NO synthase and renin in juxtaglomerular apparatus of rat kidneys. Am J Physiol Renal Physiol. 1995; 268:F1164-F1176.

33. Forssmann WG, Taugner R. Studies on the juxtaglomerular apparatus. V. The juxtaglomerular apparatus in Tupaia with special reference to intercellular contacts. Cell Tissue Res. 1977; 177:291-305. [PubMed: 402211]

34. Fowler BC, Chang YS, Laamarti A, Higdon M, Lapointe JY, Bell PD. Evidence for apical sodium proton exchange in macula densa cells. Kidney Int. 1995; 47:746-751. [PubMed: 7752573]

35. Francisco LL, Osborn JL, DiBona GF. Prostaglandins in renin release during sodium deprivation. Am J Physiol Renal Physiol. 1982; 243:F537-F542.

36. Friis UG, Jensen BL, Sethi S, Andreasen D, Hansen PB, Skott O. Control of renin secretion from rat juxtaglomerular cells by cAMP-specific phosphodiesterases. Circ Res. 2002; 90:996-1003. [PubMed: 12016266]

37. Fuson AL, Komlosi P, Unlap TM, Bell PD, Peti-Peterdi J. Immunolocalization of a microsomal prostaglandin E synthase in rabbit kidney. Am J Physiol Renal Physiol. 2003; 285:F558-F564. [PubMed: 12746259]

38. Gambaryan S, Wagner C, Smolenski A, Walter U, Poller W, Haase W, Kurtz A, Lohmann SM. Endogenous or overexpressed cGMP-dependent protein kinases inhibit cAMP-dependent renin release from rat isolated perfused kidney, microdissected glomeruli, and isolated juxtaglomerular cells. Proc Natl Acad Sci USA. 1998; 95:9003-9008. [PubMed: 9671794]

39. Golgi C. Annotazioni intorno all'istologia dei reni dell'uomo e di altri mammiferi e sull'istogenesi dei canalicoli oriniferi. Atti R Accad dei Lincei. 1889; 5:334-342.

40. Gomez RA, Chevalier RL, Everett AD, Elwood JP, Peach MJ, Lynch KR, Carey RM. Recruitment of renin gene-expressing cells in adult rat kidneys. Am J Physiol. 1990; 259:F660-F665. [PubMed: 2221104]

41. Goormaghtigh N. Les segments neuro-myo-arteriels juxtaglomerulaires du rein. Arch Biol. 1932; 43:575-591.

42. Goormaghtigh N. L'appareil neuro-myo-arteriel juxtaglomerulaire du rein; ses reactions en pathologie et ses rapports avec le tube urinifere. C R Soc Biol. 1937; 124:293-296.

43. Greenberg SG, He XR, Schnermann JB, Briggs JP. Effect of nitric oxide on renin secretion. I. Studies in isolated juxtaglomerular granular cells. Am J Physiol. 1995; 268:F948-F952. [PubMed: 7771523]

44. Greenberg SG, Lorenz JN, He XR, Schnermann JB, Briggs JP. Effect of prostaglandin synthesis inhibition on macula densa-stimulated renin secretion. Am J Physiol Renal Physiol. 1993; 265:F578-F583.

45. Guan Z, Buckman SY, Miller BW, Springer LD, Morrison AR. Interleukin-1beta-induced cyclooxygenase-2 expression requires activation of both c-Jun NH2-terminal kinase and p38 MAPK signal pathways in rat renal mesangial cells. J Biol Chem. 1998; 273:28670-28676. [PubMed: 9786861]

46. Gutsche HU, Muller-Suur R, Hegel U, Hierholzer K. Electrical conductivity of tubular fluid of the rat nephron. Micropuncture study of the diluting segment in situ. Pflugers Arch. 1980; 383:113121. [PubMed: 7189855]

47. Haefliger JA, Demotz S, Braissant O, Suter E, Waeber B, Nicod P, Meda P. Connexins 40 and 43 are differentially regulated within the kidneys of rats with renovascular hypertension. Kidney Int. 2001; 60:190-201. [PubMed: 11422751]

48. Hannaert P, Alvarez-Guerra M, Pirot D, Nazaret C, Garay RP. Rat NKCC2/NKCC1 cotransporter selectivity for loop diuretic drugs. Naunyn Schmiedebergs Arch Pharmacol. 2002; 365:193-199. [PubMed: 11882915]

49. Hanner F, Chambrey R, Bourgeois S, Meer E, Mucsi I, Rosivall L, Shull GE, Lorenz JN, Eladari $\mathrm{D}$, Peti-Peterdi J. Increased renal renin content in mice lacking the $\mathrm{Na}+\mathrm{H}+$ exchanger NHE2. Am J Physiol Renal Physiol. 2008; 294:F937-F944. [PubMed: 18287398] 
50. Hansen PB, Castrop H, Briggs J, Schnermann J. Adenosine induces vasoconstriction through Gidependent activation of phospholipase $\mathrm{C}$ in isolated perfused afferent arterioles of mice. $\mathrm{J}$ Am Soc Nephrol. 2003; 14:2457-2465. [PubMed: 14514723]

51. Hansen PB, Friis UG, Uhrenholt TR, Briggs J, Schnermann J. Intracellular signalling pathways in the vasoconstrictor response of mouse afferent arterioles to adenosine. Acta Physiol (Oxf). 2007; 191:89-97. [PubMed: 17565566]

52. Harding P, Sigmon DH, Alfie ME, Huang PL, Fishman MC, Beierwaltes WH, Carretero OA. Cyclooxygenase- 2 mediates increased renal renin content induced by low-sodium diet. Hypertension. 1997; 29:297-302. [PubMed: 9039118]

53. Harris RC. Interactions between COX-2 and the renin-angiotensin system in the kidney. Acta Physiol Scand. 2003; 177:423-427. [PubMed: 12648159]

54. Harris RC, McKanna JA, Akai Y, Jacobson HR, Dubois RN, Breyer MD. Cyclooxygenase-2 is associated with the macula densa of rat kidney and increases with salt restriction. J Clin Invest. 1994; 94:2504-2510. [PubMed: 7989609]

55. Hartner A, Cordasic N, Goppelt-Struebe M, Veelken R, Hilgers KF. Role of macula densa cyclooxygenase-2 in renovascular hypertension. Am J Physiol Renal Physiol. 2003; 284:F498F502. [PubMed: 12429553]

56. He XR, Greenberg SG, Briggs JP, Schnermann J. Effects of furosemide and verapamil on the $\mathrm{NaCl}$ dependency of macula densa-mediated renin secretion. Hypertension. 1995; 26:137-142. [PubMed: 7607716]

57. He XR, Greenberg SG, Briggs JP, Schnermann JB. Effect of nitric oxide on renin secretion. II. Studies in the perfused juxtaglomerular apparatus. Am J Physiol Renal Physiol. 1995; 268:F953F959.

58. Hocherl K, Kammerl MC, Schumacher K, EndemannD, Grobecker HF, Kurtz A. Role of prostanoids in regulation of the renin-angiotensin-aldosterone system by salt intake. Am J Physiol Renal Physiol. 2002; 283:F294-F301. [PubMed: 12110513]

59. Hocherl K, Wolf K, Castrop H, Ittner KP, Bucher M, Kees F, Grobecker HF, Kurtz A. Renocortical expression of renin and of cyclooxygenase- 2 in response to angiotensin II AT1 receptor blockade is closely coordinated but not causally linked. Pflugers Arch. 2001; 442:821827. [PubMed: 11680613]

60. Itoh S, Carretero OA. Role of the macula densa in renin release. Hypertension. 1985; 7:I49-I54. [PubMed: 3888838]

61. Itoh S, Carretero OA, Murray RD. Possible role of adenosine in the macula densa mechanism of renin release in rabbits. J Clin Invest. 1985; 76:1412-1417. [PubMed: 2997277]

62. Jackson EK. Adenosine: a physiological brake on renin release. Annu Rev Pharmacol Toxicol. 1991; 31:1-35. [PubMed: 2064369]

63. Jensen BL, Kurtz A. Differential regulation of renal cyclooxygenase mRNA by dietary salt intake. Kidney Int. 1997; 52:1242-1249. [PubMed: 9350647]

64. Jensen BL, Schmid C, Kurtz A. Prostaglandins stimulate renin secretion and renin mRNA in mouse renal juxtaglomerular cells. Am J Physiol Renal Physiol. 1996; 271:F659-F669.

65. Kaissling B, Kriz W. Structural analysis of the rabbit kidney. Adv Anat Embryol Cell Biol. 1979; 56:1-123. [PubMed: 443090]

66. Kaissling B, Peter S, Kriz W. The transition of the thick ascending limb of Henle's loop into the distal convoluted tubule in the nephron of the rat kidney. Cell Tissue Res. 1977; 182:111-118. [PubMed: 884723]

67. Kammerl MC, Nusing RM, Richthammer W, Kramer BK, Kurtz A. Inhibition of COX-2 counteracts the effects of diuretics in rats. Kidney Int. 2001; 60:1684-1691. [PubMed: 11703585]

68. Kammerl MC, Nusing RM, Seyberth HW, Riegger GA, Kurtz A, Kramer BK. Inhibition of cyclooxygenase- 2 attenuates urinary prostanoid excretion without affecting renal renin expression. Pflugers Arch. 2001; 442:842-847. [PubMed: 11680616]

69. Kaplan MR, Plotkin MD, Brown D, Hebert SC, Delpire E. Expression of the mouse $\mathrm{Na}-\mathrm{K}-2 \mathrm{Cl}$ cotransporter, $\mathrm{mBSC} 2$, in the terminal inner medullary collecting duct, the glomerular and extraglomerular mesangium, and the glomerular afferent arteriole. J Clin Invest. 1996; 98:723730. [PubMed: 8698864] 
70. Keeton TK, Campbell WB. The pharmacologic alteration of renin release. Pharmacol Rev. 1980; 32:81-227. [PubMed: 7012850]

71. Kihara M, Umemura S, Kadota T, Yabana M, Tamura K, Nyuui N, Ogawa N, Murakami K, Fukamizu A, Ishii M. The neuronal isoform of constitutive nitric oxide synthase is up-regulated in the macula densa of angiotensinogen gene-knockout mice. Lab Invest. 1997; 76:285-294. [PubMed: 9042165]

72. Kihara M, Umemura S, Sugaya T, Toya Y, Yabana M, Kobayashi S, Tamura K, Kadota T, Kishida R, Murakami K, Fukamizu A, Ishii M. Expression of neuronal type nitric oxide synthase and renin in the juxtaglomerular apparatus of angiotensin type-1a receptor gene-knockout mice. Kidney Int. 1998; 53:1585-1593. [PubMed: 9607188]

73. Kim SM, Chen L, Mizel D, Huang YG, Briggs JP, Schnermann J. Low plasma renin and reduced renin secretory responses to acute stimuli in conscious COX-2-deficient mice. Am J Physiol Renal Physiol. 2007; 292:F415-F422. [PubMed: 16954340]

74. Kim SM, Mizel D, Huang YG, Briggs JP, Schnermann J. Adenosine as a mediator of macula densa-dependent inhibition of renin secretion. Am J Physiol Renal Physiol. 2006; 290:F1016F1023. [PubMed: 16303857]

75. Kirchner KA, Kotchen TA, Galla JH, Luke RG. Importance of chloride for acute inhibition of renin by sodium chloride. Am J Physiol. 1978; 235:F444-F450. [PubMed: 31796]

76. Komhoff M, Jeck ND, Seyberth HW, Grone HJ, Nusing RM, Breyer MD. Cyclooxygenase-2 expression is associated with the renal macula densa of patients with Bartter-like syndrome. Kidney Int. 2000; 58:2420-2424. [PubMed: 11115075]

77. Kotchen TA, Krzyzaniak KE, Anderson JE, Ernst CB, Galla JH, Luke RG. Inhibition of renin secretion by $\mathrm{HCl}$ is related to chloride in both dog and rat. Am J Physiol. 1980; 239:F44-F49. [PubMed: 6994510]

78. Kovacs G, Komlosi P, Fuson A, Peti-Peterdi J, Rosivall L, Bell PD. Neuronal nitric oxide synthase: its role and regulation in macula densa cells. J Am Soc Nephrol. 2003; 14:2475-2483. [PubMed: 14514725]

79. Kuan CJ, Wells JN, Jackson EK. Endogenous adenosine restrains renin release during sodium restriction. J Pharmacol Exp Ther. 1989; 249:110-116. [PubMed: 2651649]

80. Kuan CJ, Wells JN, Jackson EK. Endogenous adenosine restrains renin release in conscious rats. Circ Res. 1990; 66:637-646. [PubMed: 2407369]

81. Kurtz A, Della Bruna R, Pfeilschifter J, Bauer C. Role of cGMP as second messenger of adenosine in the inhibition of renin release. Kidney Int. 1988; 33:798-803. [PubMed: 2838680]

82. Kurtz A, Gotz KH, Hamann M, Wagner C. Stimulation of renin secretion by nitric oxide is mediated by phosphodiesterase 3. Proc Natl Acad Sci USA. 1998; 95:4743-4747. [PubMed: 9539809]

83. Kurtz L, Janssen-Bienhold U, Kurtz A, Wagner C. Connexin expression in renin-producing cells. J Am Soc Nephrol. 2009; 20:506-512. [PubMed: 19073828]

84. Latta H, Maunsbach AB. The juxtaglomerular apparatus as studied electron microscopically. J Ultrastruct Res. 1962; 6:547-561. [PubMed: 14462706]

85. Leyssac PP. Changes in single nephron renin release are mediated by tubular fluid flow rate. Kidney Int. 1986; 30:332-339. [PubMed: 3537444]

86. Liu R, Pittner J, Persson AE. Changes of cell volume and nitric oxide concentration in macula densa cells caused by changes in luminal $\mathrm{NaCl}$ concentration. J Am Soc Nephrol. 2002; 13:26882696. [PubMed: 12397038]

87. Lorenz JN, Kotchen TA, Ott CE. Effect of $\mathrm{Na}$ and $\mathrm{Cl}$ infusion on loop function and plasma renin activity in rats. Am J Physiol. 1990; 258:F1328-F1335. [PubMed: 2186635]

88. Lorenz JN, Weihprecht H, He XR, Skott O, Briggs JP, Schnermann J. Effects of adenosine and angiotensin on macula densa-stimulated renin secretion. Am J Physiol Renal Physiol. 1993; 265:F187-F194.

89. Lorenz JN, Weihprecht H, Schnermann J, Skott O, Briggs JP. Characterization of the macula densa stimulus for renin secretion. Am J Physiol Renal Physiol. 1990; 259:F186-F193. 
90. Lorenz JN, Weihprecht H, Schnermann J, Skott O, Briggs JP. Renin release from isolated juxtaglomerular apparatus depends on macula densa chloride transport. Am J Physiol Renal Physiol. 1991; 260:F486-F493.

91. Mangat H, Peterson LN, Burns KD. Hypercalcemia stimulates expression of intrarenal phospholipase $A_{2}$ and prostaglandin H synthase-2 in rats. J Clin Invest. 1997; 100:1941-1950. [PubMed: 9329957]

92. Mann B, Hartner A, Jensen BL, Kammerl M, Kramer BK, Kurtz A. Furosemide stimulates macula densa cyclooxygenase-2 expression in rats. Kidney Int. 2001; 59:62-68. [PubMed: 11135058]

93. Meyer JW, Flagella M, Sutliff RL, Lorenz JN, Nieman ML, Weber CS, Paul RJ, Shull GE. Decreased blood pressure and vascular smooth muscle tone in mice lacking basolateral $\mathrm{Na}(+)-$ K(+)-2Cl(-) cotransporter. Am J Physiol Heart Circ Physiol. 2002; 283:H1846-H1855. [PubMed: 12384462]

94. Morgan T, Berliner RW. A study by continuous microperfusion of water and electrolyte movements in the loop of Henle and distal tubule of the rat. Nephron. 1969; 6:388-405. [PubMed: 5791283]

95. Morgan T, Gillies A. Factors controlling the release of renin. A micropuncture study in the cat. Pflugers Arch. 1977; 368:13-18. [PubMed: 558584]

96. Mundel P, Bachmann S, Bader M, Fischer A, Kummer W, Mayer B, Kriz W. Expression of nitric oxide synthase in kidney macula densa cells. Kidney Int. 1992; 42:1017-1019. [PubMed: 1280698]

97. Murakami K, Tsuchiya K, Naruse M, Naruse K, Demura H, Arai J, Nihei H. Nitric oxide synthase I immunoreactivity in the macula densa of the kidney is angiotensin II dependent. Kidney Int Suppl. 1997; 63:S208-S210. [PubMed: 9407461]

98. Nash FD, Rostorfer HH, Bailie MD, Wathen RL, Schneider EG. Renin release: relation to renal sodium load and dissociation from hemodynamic changes. Circ Res. 1968; 22:473-487. [PubMed: 5648055]

99. Olson RD, Skoglund ML, Nies AS, Gerber JG. Prostaglandins mediate the macula densa stimulated renin release. Adv Prostaglandin Thromboxane Res. 1980; 7:1135-1137. [PubMed: 6989182]

100. Paliege A, Mizel D, Medina C, Pasumarthy A, Huang YG, Bachmann S, Briggs JP, Schnermann JB, Yang T. Inhibition of nNOS expression in the macula densa by COX-2-derived prostaglandin E(2). Am J Physiol Renal Physiol. 2004; 287:F152-F159. [PubMed: 15010356]

101. Peti-Peterdi J, Bebok Z, Lapointe JY, Bell PD. Novel regulation of cell $[\mathrm{Na}(+)]$ in macula densa cells: apical $\mathrm{Na}(+)$ recycling by H-K-ATPase. Am J Physiol Renal Physiol. 2002; 282:F324F329. [PubMed: 11788447]

102. Peti-Peterdi J, Bell PD. Regulation of macula densa Na:H exchange by angiotensin II. Kidney Int. 1998; 54:2021-2028. [PubMed: 9853267]

103. Peti-Peterdi J, Bell PD. Cytosolic [Ca2+] signaling pathway in macula densa cells. Am J Physiol Renal Physiol. 1999; 277:F472-F476.

104. Peti-Peterdi J, Komlosi P, Fuson AL, Guan Y, Schneider A, Qi Z, Redha R, Rosivall L, Breyer $\mathrm{MD}$, Bell PD. Luminal $\mathrm{NaCl}$ delivery regulates basolateral PGE2 release from macula densa cells. J Clin Invest. 2003; 112:76-82. [PubMed: 12840061]

105. Peti-Peterdi J, Morishima S, Bell PD, Okada Y. Two-photon excitation fluorescence imaging of the living juxtaglomerular apparatus. Am J Physiol Renal Physiol. 2002; 283:F197-F201. [PubMed: 12060602]

106. Pricam C, Humbert F, Perrelet A, Orci L. Gap junctions in mesangial and lacis cells. J Cell Biol. 1974; 63:349-354. [PubMed: 4421621]

107. Reid IA, Chou L. Effect of blockade of nitric oxide synthesis on the renin secretory response to frusemide in conscious rabbits. Clin Sci (Colch). 1995; 88:657-663. [PubMed: 7543396]

108. Reinalter SC, Jeck N, Brochhausen C, Watzer B, Nusing RM, Seyberth HW, Komhoff M. Role of cyclooxygenase- 2 in hyperprostaglandin $\mathrm{E}$ syndrome/antenatal Bartter syndrome. Kidney Int. 2002; 62:253-260. [PubMed: 12081585]

109. Ren YL, Garvin JL, Carretero OA. Role of macula densa nitric oxide and cGMP in the regulation of tubuloglomerular feedback. Kidney Int. 2000; 58:2053-2060. [PubMed: 11044225] 
110. Robben JH, Fenton RA, Vargas SL, Schweer H, Peti-Peterdi J, Deen PM, Milligan G. Localization of the succinate receptor in the distal nephron and its signaling in polarized MDCK cells. Kidney Int. 2009; 76:1258-1267. [PubMed: 19776718]

111. Rostand SG, Work J, Luke RG. Effect of reduced chloride reabsorption on renin release in the isolated rat kidney. Pflugers Arch. 1985; 405:46-51. [PubMed: 3903651]

112. Salomonsson M, Gonzalez E, Westerlund P, Persson AE. Intracellular cytosolic free calcium concentration in the macula densa and in ascending limb cells at different luminal concentrations of sodium chloride and with added furosemide. Acta Physiol Scand. 1991; 142:283-290. [PubMed: 1877377]

113. Salomonsson M, Skott O, Persson AE. Influence of intra-luminal arterial pressure on renin release. Acta Physiol Scand. 1991; 141:285-286. [PubMed: 2048413]

114. Sauter A, Machura K, Neubauer B, Kurtz A, Wagner C. Development of renin expression in the mouse kidney. Kidney Int. 2008; 73:43-51. [PubMed: 17898695]

115. Schnermann, J.; Briggs, JP. Function of the juxtaglomerular apparatus: control of glomerular hemodynamics and renin secretion. In: Alpern, RJ.; Hebert, SC., editors. The kidney Physiology and pathophysiology. Elsevier Academic; Burlington: 2008. p. 589-626.

116. Schnermann J, Briggs J, Schubert G. In situ studies of the distal convoluted tubule in the rat. I. Evidence for $\mathrm{NaCl}$ secretion. Am J Physiol. 1982; 243:F160-F166. [PubMed: 7114215]

117. Schnermann J, Levine DZ. Paracrine factors in tubuloglomerular feedback: adenosine, ATP, and nitric oxide. Annu Rev Physiol. 2003; 65:501-529. [PubMed: 12208992]

118. Schnermann J, Wright FS, Davis JM, Wv S, Grill G. Regulation of superficial nephron filtration rate by tubuloglomerular feedback. Pflugers Arch. 1970; 318:147-175. [PubMed: 5464606]

119. Schricker K, Hamann M, Kurtz A. Nitric oxide and prostaglandins are involved in the macula densa control of the renin system. Am J Physiol Renal Physiol. 1995; 269:F825-F830.

120. Schricker K, Kurtz A. Liberators of NO exert a dual effect on renin secretion from isolated mouse renal juxtaglomerular cells. Am J Physiol. 1993; 265:F180-F186. [PubMed: 8396340]

121. Schricker K, Potzl B, Hamann M, Kurtz A. Coordinate changes of renin and brain-type nitricoxide-synthase (b-NOS) mRNA levels in rat kidneys. Pflugers Arch. 1996; 432:394-400. [PubMed: 8765998]

122. Schweda F, Klar J, Narumiya S, Nusing RM, Kurtz A. Stimulation of renin release by prostaglandin E2 is mediated by EP2 and EP4 receptors in mouse kidneys. Am J Physiol Renal Physiol. 2004; 287:F427-F433. [PubMed: 15113745]

123. Schweda F, Wagner C, Kramer BK, Schnermann J, Kurtz A. Preserved macula densa-dependent renin secretion in A1 adenosine receptor knockout mice. Am J Physiol Renal Physiol. 2003; 284:F770-F777. [PubMed: 12475747]

124. Sequeira Lopez ML, Pentz ES, Nomasa T, Smithies O, Gomez RA. Renin cells are precursors for multiple cell types that switch to the renin phenotype when homeostasis is threatened. Dev Cell. 2004; 6:719-728. [PubMed: 15130496]

125. Shade RE, Davis JO, Johnson JA, Witty RT. Effects of renal arterial infusion of sodium and potassium on renin secretion in the dog. Circ Res. 1972; 31:719-727. [PubMed: 5084885]

126. Singh I, Grams M, Wang WH, Yang T, Killen P, Smart A, Schnermann J, Briggs JP. Coordinate regulation of renal expression of nitric oxide synthase, renin, and angiotensinogen mRNA by dietary salt. Am J Physiol Renal Physiol. 1996; 270:F1027-F1037.

127. Skott O, Briggs JP. Direct demonstration of macula densa-mediated renin secretion. Science. 1987; 237:1618-1620. [PubMed: 3306925]

128. Skott O, Briggs JP. A method for superfusion of the isolated perfused tubule. Kidney Int. 1988; 33:1009-1012. [PubMed: 3292813]

129. Taugner, R.; Hackenthal, E. The juxtaglomerular apparatus. Springer; Berlin: 1989.

130. Taugner R, Rosivall L, Buhrle CP, Groschel-Stewart U. Myosin content and vasoconstrictive ability of the proximal and distal (renin-positive) segments of the preglomerular arteriole. Cell Tissue Res. 1987; 248:579-588. [PubMed: 3300994]

131. Taugner R, Schiller A, Kaissling B, Kriz W. Gap junctional coupling between the JGA and the glomerular tuft. Cell Tissue Res. 1978; 186:279-285. [PubMed: 627020] 
132. Theilig F, Campean V, Paliege A, Breyer M, Briggs JP, Schnermann J, Bachmann S. Epithelial COX-2 expression is not regulated by nitric oxide in rodent renal cortex. Hypertension. 2002; 39:848-853. [PubMed: 11967238]

133. Thorup C, Persson AE. Inhibition of locally produced nitric oxide resets tubuloglomerular feedback mechanism. Am J Physiol Renal Physiol. 1994; 267:F606-F611.

134. Tojo A, Madsen KM, Wilcox CS. Expression of immuno-reactive nitric oxide synthase isoforms in rat kidney. Effects of dietary salt and losartan. Jpn Heart J. 1995; 36:389-398. [PubMed: 7544416]

135. Tomasoni S, Noris M, Zappella S, Gotti E, Casiraghi F, Bonazzola S, Benigni A, Remuzzi G. Upregulation of renal and systemic cyclooxygenase-2 in patients with active lupus nephritis. $\mathrm{J}$ Am Soc Nephrol. 1998; 9:1202-1212. [PubMed: 9644630]

136. Traynor TR, Smart A, Briggs JP, Schnermann J. Inhibition of macula densa-stimulated renin secretion by pharmacological blockade of cyclooxygenase-2. Am J Physiol Renal Physiol. 1999; 277:F706-F710.

137. Vander AJ. Control of renin release. Physiol Rev. 1967; 47:359-382. [PubMed: 4864539]

138. Vander AJ. Renin secretion during mannitol diuresis and ureteral occlusion. Proc Soc Exp Biol Med. 1968; 128:518-520. [PubMed: 5663266]

139. Vander AJ, Carlson J. Mechanism of the effects of furosemide on renin secretion in anesthetized dogs. Circ Res. 1969; 25:145-152. [PubMed: 4308808]

140. Vander AJ, Miller R. Control of renin secretion in the anesthetized dog. Am J Physiol. 1964; 207:537-546. [PubMed: 14220020]

141. Vargas SL, Toma I, Kang JJ, Meer EJ, Peti-Peterdi J. Activation of the succinate receptor GPR91 in macula densa cells causes renin release. J Am Soc Nephrol. 2009; 20:1002-1011. [PubMed: 19389848]

142. Vio CP, Cespedes C, Gallardo P, Masferrer JL. Renal identification of cyclooxygenase-2 in a subset of thick ascending limb cells. Hypertension. 1997; 30:687-692. [PubMed: 9323006]

143. Wagner C, de Wit C, Kurtz L, Grunberger C, Kurtz A, Schweda F. Connexin40 is essential for the pressure control of renin synthesis and secretion. Circ Res. 2007; 100:556-563. [PubMed: 17255527]

144. Wang H, Carretero OA, Garvin JL. Inhibition of apical Na+/H+ exchangers on the macula densa cells augments tubuloglomerular feedback. Hypertension. 2003; 41:688-691. [PubMed: 12623980]

145. Wang JL, Cheng HF, Harris RC. Cyclooxygenase-2 inhibition decreases renin content and lowers blood pressure in a model of renovascular hypertension. Hypertension. 1999; 34:96-101. [PubMed: 10406830]

146. Wang JL, Cheng HF, Zhang MZ, McKanna JA, Harris RC. Selective increase of cyclooxygenase-2 expression in a model of renal ablation. Am J Physiol Renal Physiol. 1998; 275:F613-F622.

147. Weihprecht H, Lorenz JN, Schnermann J, Skott O, Briggs JP. Effect of adenosine1-receptor blockade on renin release from rabbit isolated perfused juxtaglomerular apparatus. J Clin Invest. 1990; 85:1622-1628. [PubMed: 2185276]

148. Welch WJ, Ott CE, Lorenz JN, Kotchen TA. Effects of chlorpropamide on loop of Henle function and plasma renin. Kidney Int. 1986; 30:712-716. [PubMed: 3537461]

149. Wilcox CS, Welch WJ, Murad F, Gross SS, Taylor G, Levi R, Schmidt HH. Nitric oxide synthase in macula densa regulates glomerular capillary pressure. Proc Natl Acad Sci USA. 1992; 89:11993-11997. [PubMed: 1281548]

150. Wolf K, Castrop H, Hartner A, Goppelt-Strube M, Hilgers KF, Kurtz A. Inhibition of the reninangiotensin system upregulates cyclooxygenase-2 expression in the macula densa. Hypertension. 1999; 34:503-507. [PubMed: 10489401]

151. Xie W, Herschman HR. Transcriptional regulation of prostaglandin synthase 2 gene expression by platelet-derived growth factor and serum. J Biol Chem. 1996; 271:31742-31748. [PubMed: 8940199] 
152. Yang T, Endo Y, Huang YG, Smart A, Briggs JP, Schnermann J. Renin expression in COX-2knockout mice on normal or low-salt diets. Am J Physiol Renal Physiol. 2000; 279:F819-F825. [PubMed: 11053041]

153. Yang T, Huang Y, Heasley LE, Berl T, Schnermann JB, Briggs JP. MAPK mediation of hypertonicity-stimulated cyclooxygenase-2 expression in renal medullary collecting duct cells. $\mathrm{J}$ Biol Chem. 2000; 275:23281-23286. [PubMed: 10930430]

154. Yang T, Park JM, Arend L, Huang Y, Topaloglu R, Pasumarthy A, Praetorius H, Spring K, Briggs JP, Schnermann J. Low chloride stimulation of prostaglandin E2 release and cyclooxygenase-2 expression in a mouse macula densa cell line. J Biol Chem. 2000; 275:37922_ 37929. [PubMed: 10982805]

155. Yang T, Singh I, Pham H, Sun D, Smart A, Schnermann JB, Briggs JP. Regulation of cyclooxygenase expression in the kidney by dietary salt intake. Am J Physiol Renal Physiol. 1998; 274:F481-F489.

156. Zhang J, Hill CE. Differential connexin expression in preglomerular and postglomerular vasculature: accentuation during diabetes. Kidney Int. 2005; 68:1171-1185. [PubMed: 16105048]

157. Zhang MZ, Yao B, Fang X, Wang S, Smith JP, Harris RC. Intrarenal dopaminergic system regulates renin expression. Hypertension. 2009; 53:564-570. [PubMed: 19139376]

158. Zhang MZ, Yao B, McKanna JA, Harris RC. Cross talk between the intrarenal dopaminergic and cyclooxygenase-2 systems. Am J Physiol Renal Physiol. 2005; 288:F840-F845. [PubMed: 15613619]

159. Zimmermann KW. Ueber den Bau des Glomerulus der Saeugerniere. Z Mikr Anat Forsch. 1933; $32: 176-278$. 


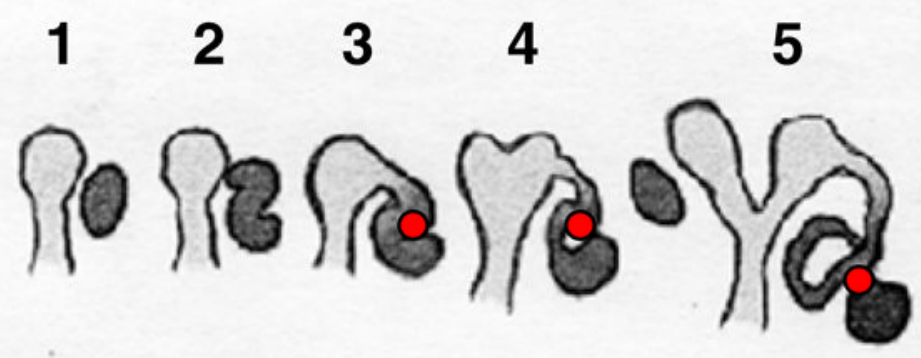

6

7
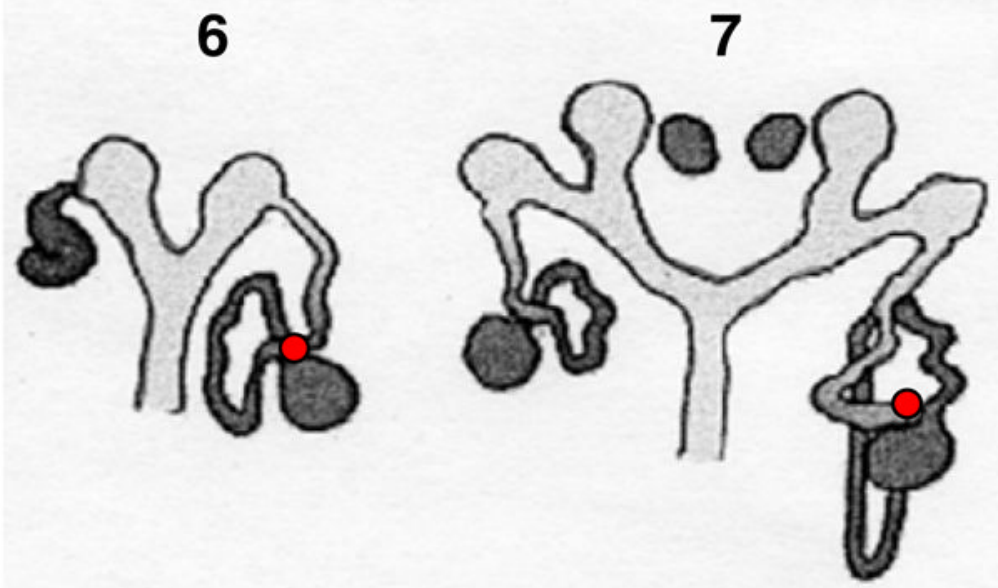

Fig. 1.

Schematic representation of nephrogenesis. During nephron development, a cellular contact region is established between the glomerulus and the tubular compartment at the stage of the S-shaped body (2). The proximal tubule and loop of Henle develop from the lower arm of the S, preserving this contact throughout nephrogenesis (red dot). Light gray ureteral bud, dark gray mesenchymal 

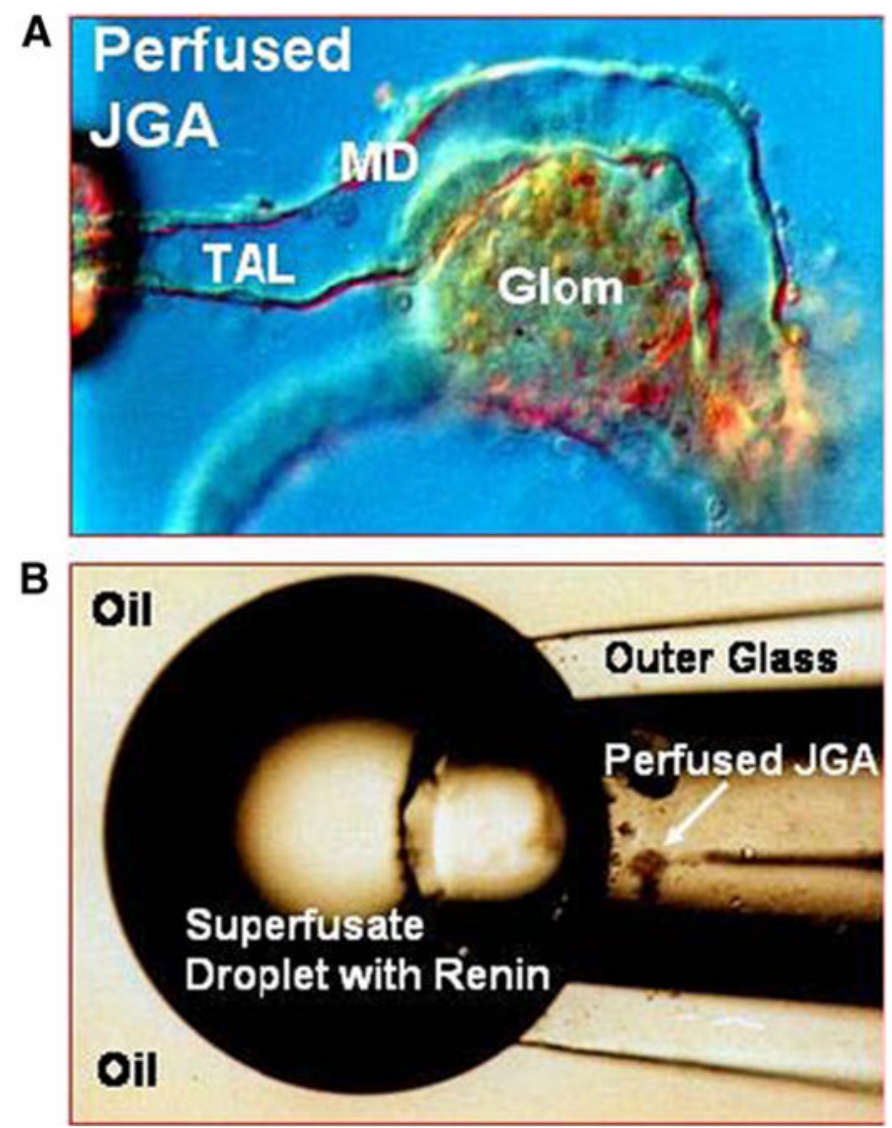

Fig. 2.

Use of the isolated perfused tubule of the rabbit to assess MD-mediated renin secretion. a Microphotograph of a perfused segment of the thick ascending limb (TAL) with attached glomerulus (Glom); macula densa $(M D)$ cells in the rabbit protrude into the tubular lumen; holding and perfusion pipettes can be seen on the far left. b To measure renin secretion, the perfused JGA is placed in a superfusion chamber and immersed in mineral oil so that the emerging superfusate is forming a bubble that is collected in intervals and analyzed for renin 

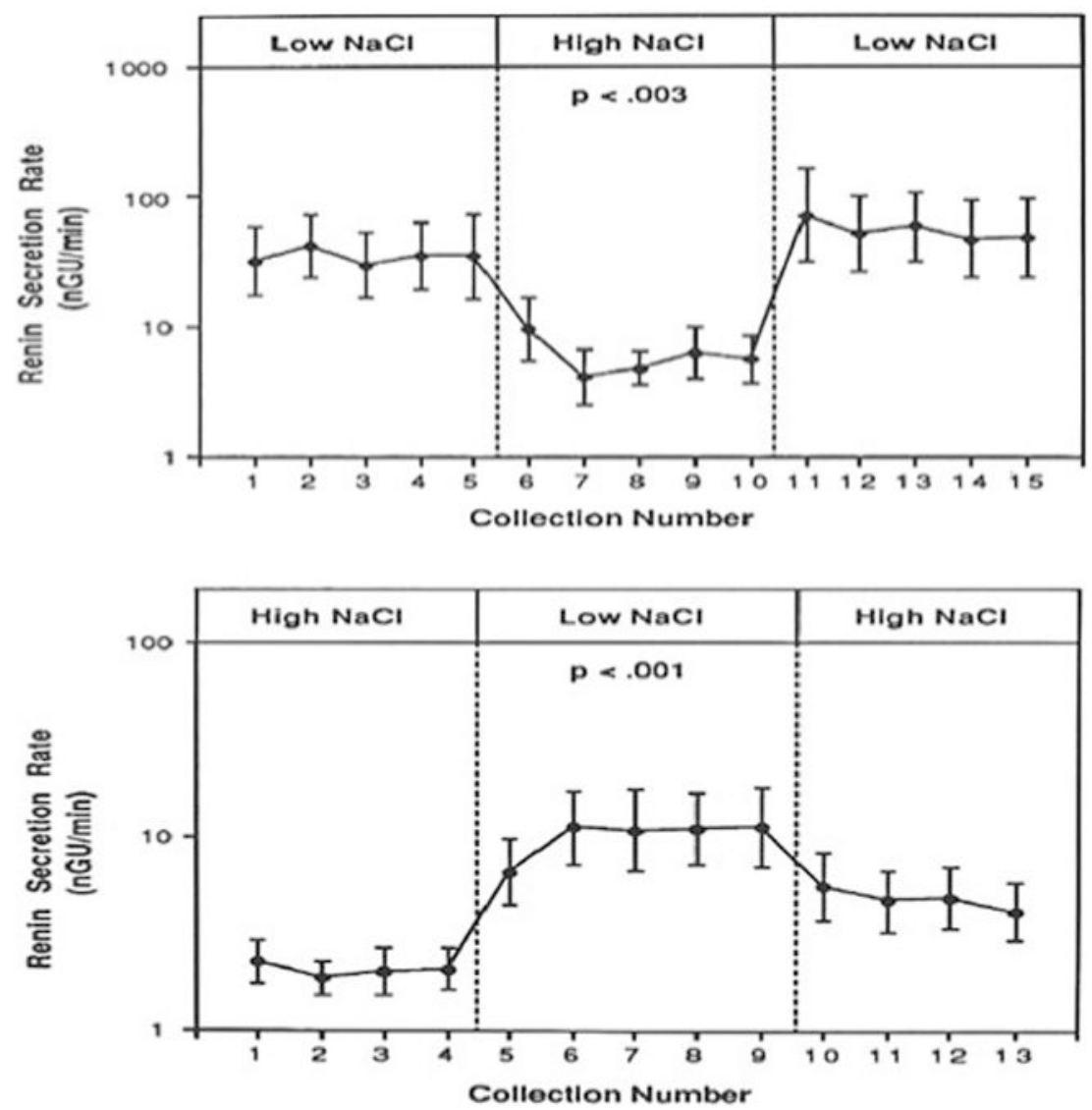

Fig. 3.

Macula densa mediated changes in renin secretion is the isolated perfused JGA preparation, in which perfusate $\mathrm{NaCl}$ concentration was changed from low to high $\mathrm{NaCl}$ (upper panel) and from high to low (lower panel). Collection intervals are $10 \mathrm{~min}$. Results are from [89] 
A

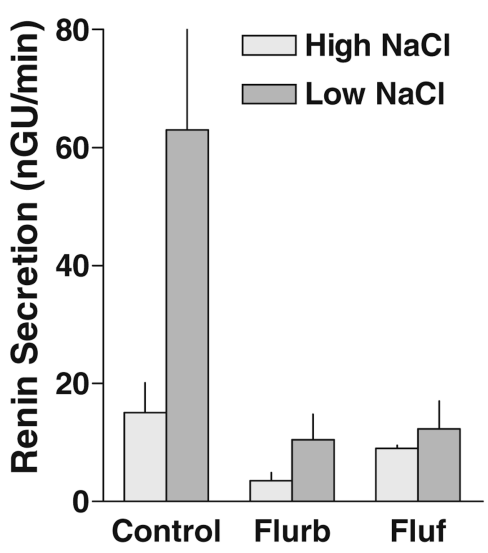

B

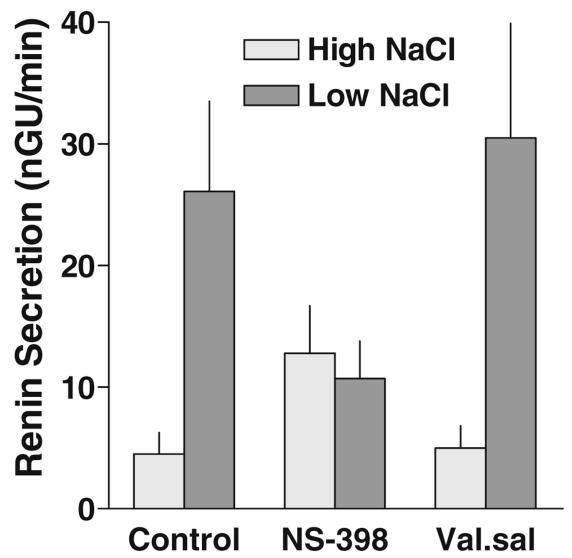

Fig. 4.

Effect of COX-2 inhibition on MD-dependent renin release in the isolated perfused JGA. a Renin secretion during perfusion at high and low $\mathrm{NaCl}$ in the absence and presence of the COX inhibitors flurbiprofen (Flurb; $10^{-5} \mathrm{M}$ ) or flufenamic acid (Fluf, $10^{-4} \mathrm{M}$ ) (data redrawn from [44]). b Renin secretion during perfusion at high and low $\mathrm{NaCl}$ in the absence and presence effect of NS-398 $(50 \mu \mathrm{M})$ and valerylsalicylate (Val.sal., $500 \mu \mathrm{M})$ (data redrawn from [136]) 

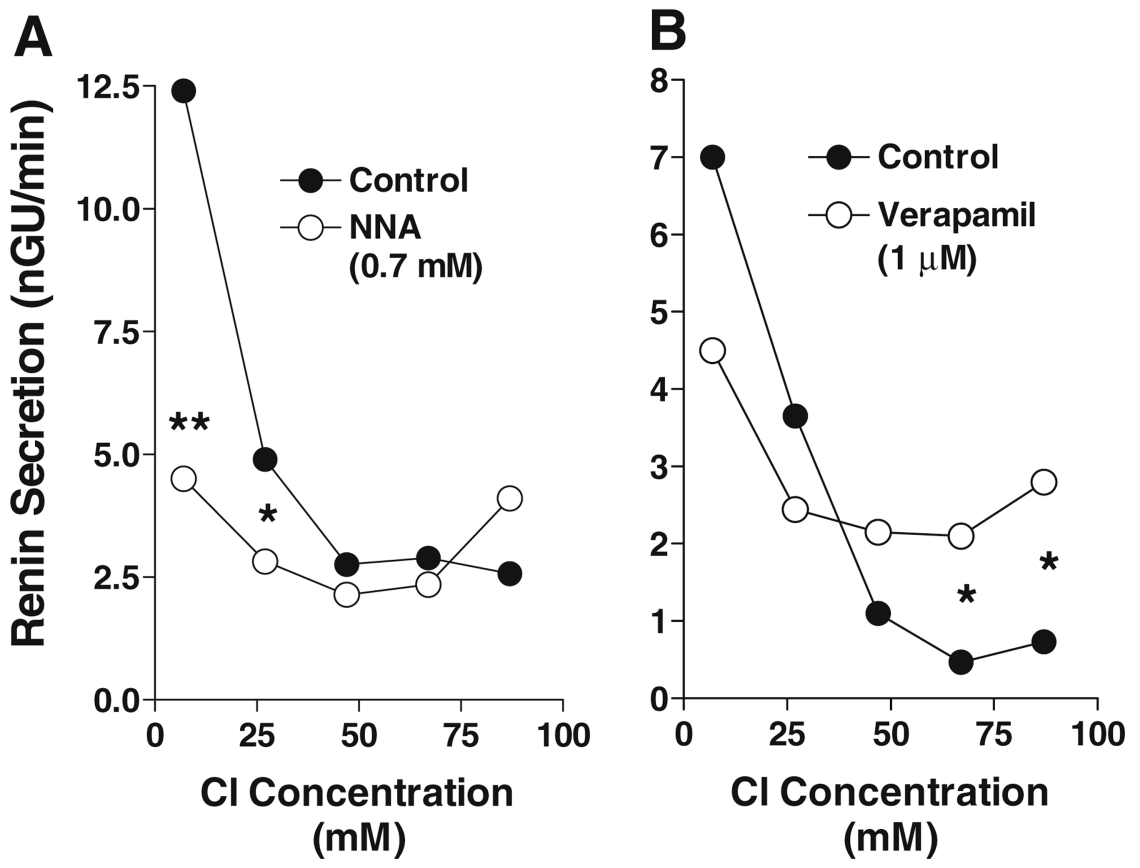

Fig. 5.

$\mathrm{NaCl}$ dependency of renin release in the perfused JGA preparation. a Comparison between control and perfusion with $N^{\omega}$-nitro-L-argi-nine $(L-N N A ; 0.7 \mathrm{mM})$ (data redrawn from [57]); b comparison between control and perfusion with $1 \mu \mathrm{M}$ verapamil (data redrawn from [56]) 
A
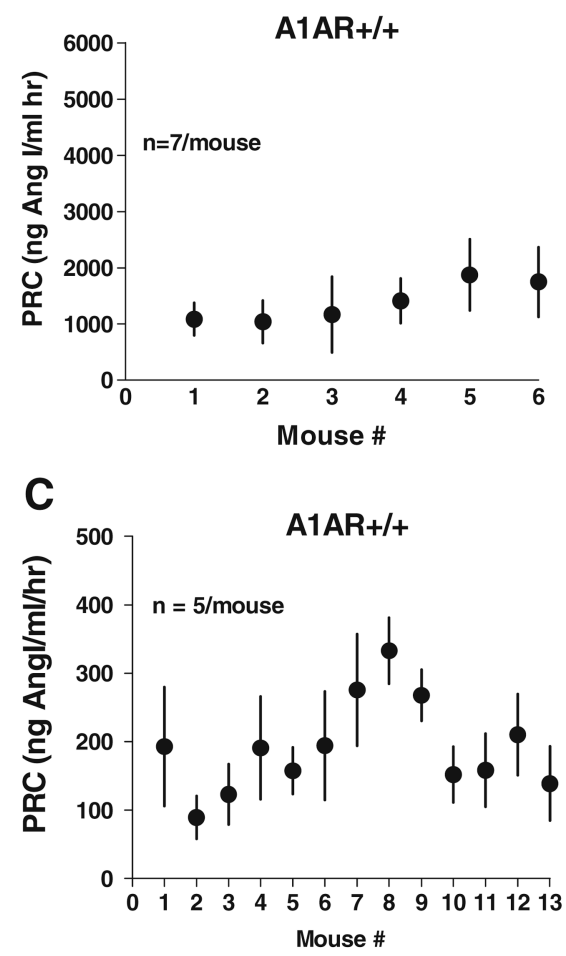

B

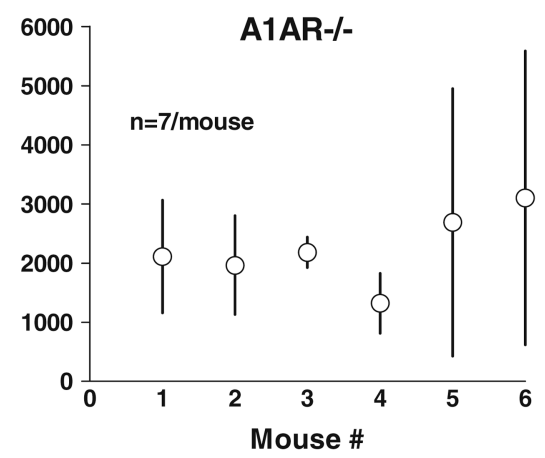

D

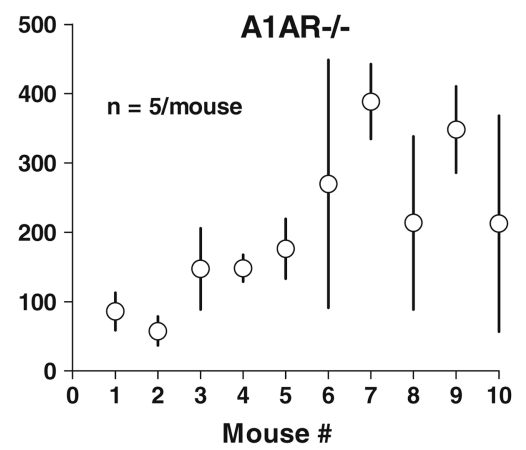

Fig. 6.

Variability of repeat measurements of plasma renin concentration $(P R C)$ in wild-type (a, $\mathbf{c})$ and A1AR-deficient mice (b, d) in two independent experimental series (a, b vs. c, d). Variability is indicated by vertical lines representing standard deviations of measurements in individual mice. Note greater variability in $\mathrm{A}_{1} \mathrm{AR}^{-/}$mice in both series. Also note that PRC values of wild-type mice are quite constant in individual wild-type mice, but that they can vary between mice by a factor of 2-3. a, b Measurements performed on six wild-type and six mutant mice with seven independent measurements per animal over 2 weeks (Soo Mi Kim et al., unpublished data). c, $\mathbf{d}$ Measurements performed on 13 wild-type and ten mutant mice with five measurements per animal over 10 days (Hayo Castrop et al., unpublished data). Differences in PRC between the two series are due to assay differences 